\title{
Article
}

\section{Serum Total Protein and Albumin Levels in Different Grades of Protein Energy Malnutrition}

\author{
Chowdhury MSI ${ }^{1}$, Akhter $\mathbf{N}^{2}$, Haque $\mathbf{M}^{3}$, Aziz $\mathbf{R}^{4}$, Nahar $\mathbf{N}^{5}$
}

The present study has been designed to estimate serum total protein and albumin levels in different grades of protein energy malnutrition and this will be helpful in early diagnosis, management and rehabilitation of PEM. The serum total protein and albumin levels were studied on 20 healthy children and 30 children suffering from protein energy malnutrition of different grades.

Serum total protein and albumin levels of different grades of protein energy malnutrition were significantly lowered than that of control. Lowering being maximum in grade III PEM. This lowering of total protein and albumin occur in any form of PEM and related to severity of the disease.

Key Words: Serum, Protein, Malnutrition

J Bangladesh Soc Physiol.2008 Dec;(3):58-60.

For author affiliations, see end of text.

http://www.banglajol.info/index.php/JBSP

\section{Introduction}

$\mathbf{M}$ alnutrition is one of the common public health problem and observe a leading cause of mortality in

Bangladesh. Children under 06 years are victims of different grades of malnutrition ${ }^{1}$. Children with PEM have greater deficient of Total Protein and in severe cases the total protein may be reduced to around $50 \%^{2}$. The reductions of total serum protein and albumin were more marked in kwashiorkor than in marasmus.

Physical findings generally help in the diagnosis of advanced malnutrition but is not frequently positive in children in mild and moderated degree of malnutrition. Early diagnosis of these cases is very useful, as they are amenable to early rehabilitation, have better prognosis. ${ }^{3,4}$

The assay of total protein and albumin will prove very useful in the diagnosis of PEM before clinical manifestations are established and thus help in reducing problem created by $\mathrm{PEM}^{5}$.

\section{Methods}

The study was carried out in a total number of 50 children of 06 months to 05 years of age of both sexes and out of them twenty of apparently healthy children with no systemic disorder and in terms of median Harvard standard Weight/ Height ratio more than $80 \%$ were taken as control group. Thirty children suffering from various grades of PEM of same age and both sexes were selected as experimental group and excludes hepatobiliary and other disease by history and physical examination 30 children with PEM of both sexes in the age group of 6 month to 5 years were selected for the study the attendant parents of the patients was put through a questioners to collect data related to the study and verbal consent were taken from them for

J Bangladesh Soc Physiol. 2008 Dec;(3):58-60 
participation his/her child in the study. Experimental groups were collected from BSMMU, child nutrition unit of Dhaka Shisu Hospital and Dhaka Medical College Hospital, Dhaka.

Grade - I, II and III PEM cases were selected according to classification set by Gomez, shown in Table- I.

Table - I Gomez classification of PEM

\begin{tabular}{lc}
\hline Degree of PEM & $\begin{array}{r}\text { \% of desired } \\
\text { body wt. for } \\
\text { age \& sex }\end{array}$ \\
\hline Normal & $90 \%-100 \%$ \\
Grade -I. Mild Malnutrition & $75 \%-89 \%$ \\
Grade - II. Moderate Malnutrition & $60 \%-74 \%$ \\
Grade -III, Severe Malnutrition & $<60 \%$ \\
\hline
\end{tabular}

Another classification of PEM based on Height for age and weight for height called water low classification is shown in Table - II.
Table - II

Waterlow classification of PEM

\begin{tabular}{lcc}
\hline $\begin{array}{l}\text { Degree of } \\
\text { PEM }\end{array}$ & $\begin{array}{c}\text { Stunting (\%) } \\
\text { Height for age }\end{array}$ & $\begin{array}{c}\text { Wasting (\%) } \\
\text { weight for height }\end{array}$ \\
\hline Normal & $90 \%$ & $90 \%$ \\
Mild & $87.5-95 \%$ & $80-90 \%$ \\
Moderate & $80-87.5 \%$ & $70-80 \%$ \\
Severe & $<80 \%$ & $<70 \%$ \\
\hline
\end{tabular}

Blood was drawn with all aseptic precaution and serum total protein was determined by colorimetric Biuret method. Albumin was determined by colorimetric Bromcresolgreen method. Statistical analysis of the result was done by unpaired student " $t$ ”test.

\section{Results}

Serum total protein and albumin levels in grade I, grade - II and grade III. PEM are significantly lowered $(\mathrm{P}<0.001)$ than that of control (Table III). Serum total protein and albumin levels in grade III, PEM are significantly lowered $(\mathrm{P}<0.001)$ than that of grade II and grade I, PEM. When comparison was done between grade II PEM and grade I PEM, it was found that serum total protein and albumin levels in grade II PEM was significantly lower that of grade I PEM.

Table - III

Mean ( \pm SE) serum total protein and albumin levels in control and different grades of PEM.

\begin{tabular}{lcccc}
\hline Parameters & Control & Grade-I PEM & Grade-II PEM & Grade-III PEM \\
& $\mathrm{n}=20$ & $\mathrm{n}=10$ & $\mathrm{n}=10$ & $\mathrm{n}=10$ \\
\hline Total protein $(\mathrm{gm} / \mathrm{dl})$ & $7.02 \pm 0.14$ & $5.15 \pm 0.26 * * *$ & $4.6 \pm 0.09 * * *$ & $4.0 \pm 0.08^{* * *}$ \\
Albumin(gm/dl) & $4.46 \pm 0.06$ & $3.38 \pm 0.13^{* * *}$ & $3.12 \pm 0.12^{* * *}$ & $2.6 \pm 0.11^{* * *}$ \\
\hline
\end{tabular}

*** $\mathrm{P}<0.001=$ Highly significant

\section{Discussion}

In this study serum total protein and albumin values in all grades of PEM are significantly lowered than control. Lowering of these serum total protein and albumin values in PEM could be explained on the basis of generalized

J Bangladesh Soc Physiol. 2008 Dec;(3):58-60 protein deficiency leading to impaired synthesis. These results are in agreement to that of other workers. ${ }^{2,4,5,6,7}$ In the final stage of wasting low plasma albumin concentration can appear because of feature of adaptation of protein deficient diet ${ }^{5}$. 
In the development of mararasmus, there occur deficiencies of energy in the diet reselling in the change of normal pattern ${ }^{4}$.

It is also observed that reduction in serum albumin and total protein in PEM was due to reduced synthesis of protein because of inadequate intake of dietary protein ${ }^{9}$.

\section{Conclusion}

It may conclude that serum total protein and albumin were significantly lowered in protein energy malnutrition and this varies according to its severity. The result may help physician to diagnose PEM and could help to detect its severity.

\section{Author Affiliations}

1. * Md Serajul Islam Chowdhury, Assistant Professor of Biochemistry, Chittagong Medical College, Chittagong, Bangladesh

2. Nayeema Akhter, Professor of Physiology, Chittagong Medical College, Chittagong, Bangladesh

3. Mahmudul Haque, Professor of biochemistry, Chittagong Medical College, Chittagong, Bangladesh

4. Rehana Aziz, Assistant Professor of Biochemistry, Chittagong Medical College, Chittagong, Bangladesh

5. Nazibun Nahar, Lecturer of Biochemistry, Chittagong Medical College, Chittagong, Bangladesh

* For correspondence

\section{References}

1. Bangladesh bureaus of statistics. Report of the child nutrition status survey, 1995-96. Dhaka. Bangladesh Bureau of Statistics, 1996-:22-39.

2. Montogomery RD. Muscle morphology in infantile protein energy malnutrition. J Clin Path 1962;15:511-21.

3. Bengoa JM. Recent trends in the public health aspects of protein calorie malnutrition WHO Chron 1979;24:552-61.

4. Coward WA \& Lunn PG. The Biochemistry and physiology of kwashiorkor and marasmus. Br Med Bulletin 1981;37(1):19-24.

5. Coward BWA, Whitehead RG \& Lunn PG. Reasons why hypoalbuninaemia mayor may not appear in protein energy malnutrition. Br J Nutr 1977;38:115-26.

6. Coward BWA, Whitehead RG \& Coward DG. Quantitative changes in serum protein fractions during the development of kwashiorkor and in recovery. $\mathrm{Br} \mathrm{J}$ Nutr 1972;28: 433-41.

7. Kumer V, Chandrasckharan R, Belavalgidad M.I. Blood biochemical tests in the diagnosis of malnutrition. Indian pediatrics 1975;12(10):955-60.

8. Bhattacharya AK. Studies on Kwashiorkor and Marasmus in Calcutta (1957-74): Pathological, Biochemical and metabolic studies. Indian J Pediatrics 1975;12:1115-21.

9. Osifo Boa \& Bloodekujo. Serum aspartate and alanine aminotransferase activities in protein energy malnutrition. Enzymes 1982;28:300-4. 